\title{
Relationship between personality traits and coping styles with distress tolerance during coronavirus outbreak
}

\author{
Najmeh Alsadat Hodaei ${ }^{1}$, Batool Ahadi ${ }^{2}$, Azam Farah Bijari ${ }^{3}$ \\ 1-MSc, Department of Psychology, Alzahra University, Tehran, Iran (Corresponding Author). \\ E-mail: Hodaeenajme @gmail.com \\ 2- Associate Professor, Department of Psychology, Alzahra University, Tehran, Iran. \\ 3- Assistant Professor, Department of Psychology, Alzahra University, Tehran, Iran.
}

Received: 19/08/2021

Accepted: 23/11/2021

\begin{abstract}
Introduction: Covid-19 disease, in addition to the serious damage it has done to the physical health of the people, has caused a great deal of psychological distress, which makes it necessary to understand the factors associated with tolerating distress during this period.
\end{abstract}

Aim: The purpose of this research was to ascertain the predictive value of personality factors and coping methods for distress tolerance during coronavirus outbreaks.

Method: The current research used a descriptive-correlational approach. The statistical population consisted of all residents of Tehran aged 18-60 who engaged in the study as online in 2020. The sample size was established using the Cramer formula to be 280 individuals, and they were chosen using a non-random selection approach. Distress Tolerance Questionnaires (DTS), Coping Strategies Questionnaires (WOCQ), and the Neo Personality Questionnaire were used in the study (NEO-FFI). Multiple regression analysis was performed using SPSS software version 25 .

Results: Personality traits of extroversion, flexibility and agreeing have a positive effect and neurosis have a negative and the most effect on the degree of distress tolerance during coronary heart disease $(\mathrm{P}=0.001)$. Problematic strategies have a positive effect and emotion-oriented strategies have a negative and the most effect on the degree of distress tolerance of individuals during coronary heart disease $(\mathrm{P}=0.001)$.

Conclusion: According to this study's results, personality characteristics and coping methods are critical in predicting distress tolerance during coronavirus outbreaks. As a result, it can be concluded that paying attention to individual personality characteristics, particularly neuroticism and emotion-oriented coping strategies, and providing specialized training and counseling to these individuals during the corona pandemic can be effective in increasing distress tolerance.

Keywords: Covid-19 virus, Personality traits, Stress coping style, Distress tolerance

\footnotetext{
How to cite this article: Alsadat Hodaei N, Ahadi B, Farah Bijari A. Relationship between personality traits and coping styles with distress tolerance during coronavirus outbreak. Shenakht Journal of Psychology and Psychiatry. 2022; 8 (6): 37-49 .URL: http://shenakht.muk.ac.ir/article-1-1252-en.pdf
}

Copyright $(92018$ the Author (s). Published by Kurdistan University of Medical Sciences. This is an open access article distributed under the terms of the Creative Commons Attribution-Non Commercial License 4.0 (CCBY-NC), where it is permissible to download, share, remix, transform, and buildup the work provided it is properly cited. The work cannot be used commercially without permission from the journal. 


\title{
رابطه ويثَى هاى شخصيتى و سبكهاى مقابلهاى با تحمل بريشانى در دوران شيوع ويروس كرونا
}

\author{
نجمه السادات هدايى' ، بتول احدى '، اعظم فرح بيجارى \\ ا. كارشناسى ارشد، كروه روانشناسى، دانشكاه الزهرا، تهران، ايران (مولف مسئول). ايميل: Hodaeenajme@ gmail.com

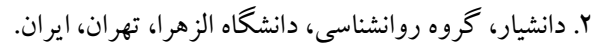

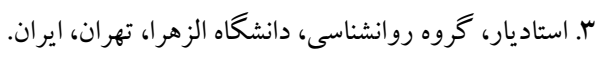

مقدمه: بيمارى كوويد-هو اعلاوه بر آسيبهاى جدى كه براى سلامت جسمى مردم ايجاد كرده، بريشانى روانشناختى فراوانى رابه بار

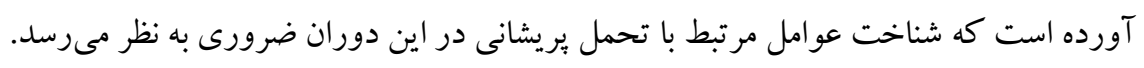
هدف: بزوهش حاضر با هدف تعيين نقش ويز گىهاى شخصيتى و سبك هاى مقابلهاى در بيشبينى تحمل بريشانى در دوران شيوع ويروس كرونا انجام شد.

روش: يزوهش حاضر از نوع مطالعات توصيفى - همبستخى بود. جامعه آمارى شامل كليه افراد .4-4 سال ساكن شهر تهران بود كه

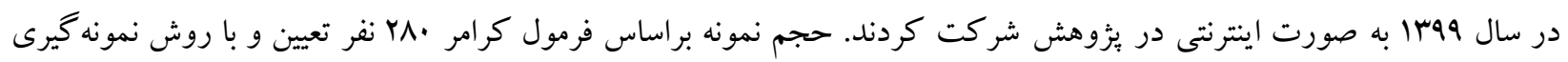

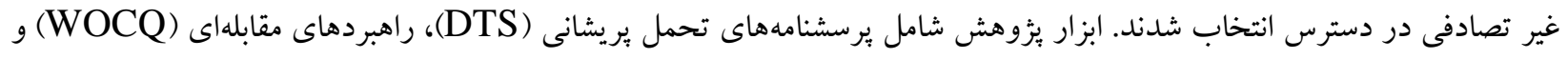

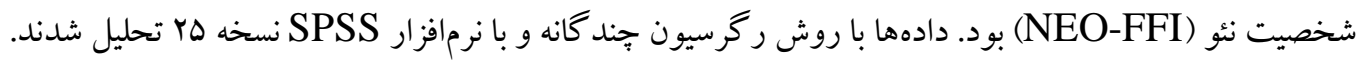
يافته ها: ويز گىهاى شخصيتى برونگر ايى، انعطافيذيرى و موافق بودن تأثير مثبت و روان رنجورى تأثير منفى و بيشترين تأثير را بر

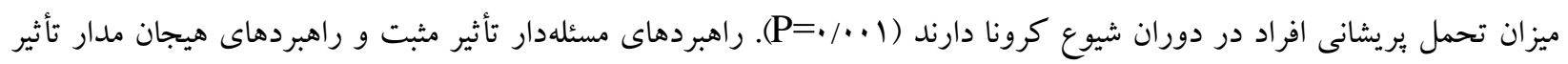

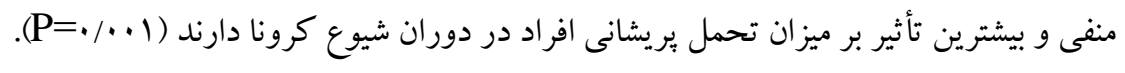
نتيجه كيرى: براساس يافتهاى اين بزوهش، ويز گىهاى شخصيتى و سبككهاى مقابلهاى در بيشبينى تحمل بريشانى در دوران شيوع

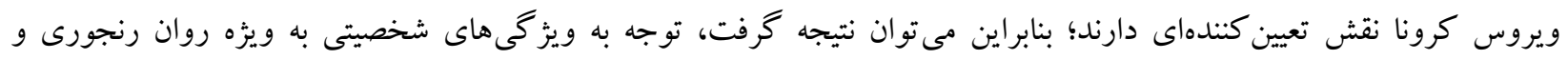

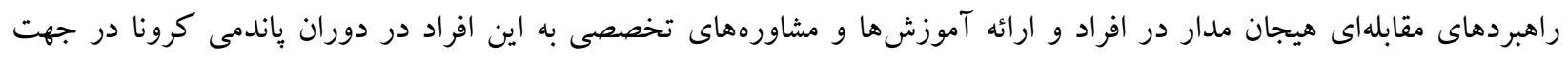
ارتقاى سطح تحمل بريشانى مى تو اند مؤثر باشد. كليدوازهها: كرونا ويروس، ويز گى هاى شخصيتى، سبك مقابله با استرس، تحمل يريشانى 
فعاليتهاى روزمره، موجب مىشود تا افراد سالم نيز با

مقلدمه

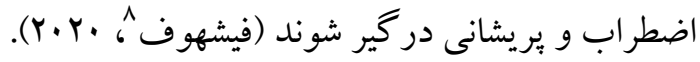
وجود جنين اضطراب و تنشهايى كه همراه اين بيمارى همه گير در سطح جهان رخ داده است، شناخت ويز كى هاى روانشناختى كه بتو اند به عنوان توانايى مقابله با اين هيجانات منفى به افراد در اين دوران كمكك نمايد، نيازمند بررسى و مطالعه است. يكى از تو انمندىهاى روانشناختى كه مىتوان به آن اشاره نمود، تحمل بريشانى است.

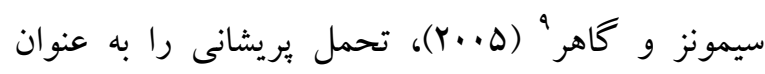
توانايى ادراكك شده خود گزارشى يكك فرد براى تجربه و تحمل حالتهاى هيجانى منفى يا توانايى رفتارى در مداومت بر رفتار معطوف به هدف در زمان تجربه يريشانى عاطفى تعريف نمودند (كراتوويج، اسميت و

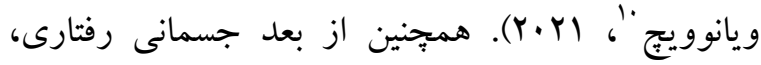
تحمل بريشانى به عنوان توانايى براى تحمل حالتهاى فيزيولوزيكى آزارنده تعريف مىشود (مكى كيلوبٍ و و

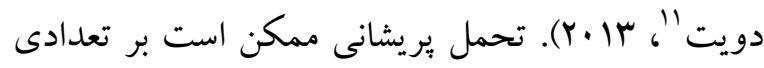
از فرايندهاى مربوط به خودتنظيمى شامل توجه، ارزيابى هاى شناختى وضعيتهاى هيجانى يا جسمانى يريشانىآور اثر بخذارد يا تحت تأثير آنها قرار بخيرد. براى مثال، تفاوتهاى فردى در تجربه هيجانها- هم شدت و هم فراوانىشان- ممكن است ماهيت تحمل بريشانى را تحت تأثير قرار دهد. افراد با سطوح كمتر تحمل يريشانى ممكن است در معرض بِاسخ ناساز گارانه به بريشانى و شرايط

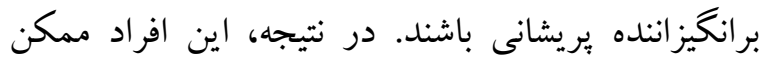
است براى اجتناب از احساسهاى منفى/ يا حالتهاى آزارنده مربوط بكوشند. در مقابل، افراد با سطوح بالاتر

${ }^{8}$ - Fischhoff

${ }^{9}$ - Simons \& Gaher

${ }^{10}$ - Kratovic, Smith \& Vujanovic

${ }^{11}$ - Mackillop \& De Wit
يكى از عواملى كه در روزهاى اخير استرس و مه وان بريشانىهاى روانى زيادى در عموم جمعيت ايجاد كرده است، شيوع بيمارى حاد تنفسى ناشى از ويروس كرونا'

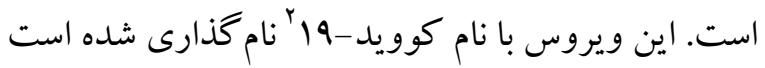
و شيوع آن از دسامبر سال •r.r.r در يوهان جين آغاز شده

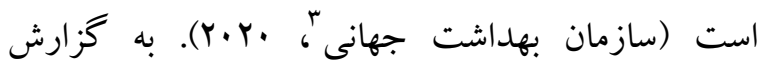
سازمان بهداشت جهانى، مردم كشورهاى مختلف در دنيا

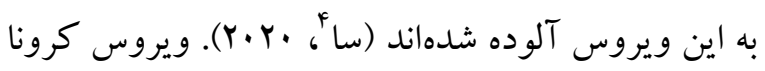
در ايران نيز به سرعت شيوع يافته و سلامت جسمى و روانى افراد را به خطر انداخته است (على يور، قدمى، على بور و عبدالله زاده، يهوب(1). يثوهشها نشان مىدهند كه بروز بيمارىهايى مانند بيمارىهاى تنفسى به علت مشكلات جدى جسمانى و كاهش كيفيت زندگى بيماران باعث بروز اضطراب ناشى به به از بيمارى خواهند شد (وو و مكك كو گانه؛ .Y.Y.

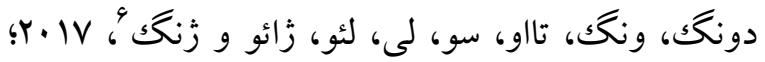

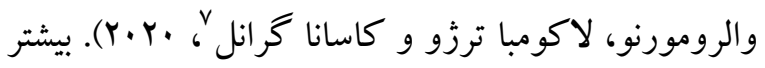
تحقيقات بر اضطراب بيماران تمركز دارند؛ اما واقعيت آن است كه در زمان همه گيرى يكك بيمارى مانند كرونا، ترس از بيمارى و ترس از مركَ، در كنار آشفتكى فعاليتهاى روزمره، موجب مىشود تا افراد سالم نيز با اضطراب بيمارى بيماران تمركز دارند؛ اما واقعيت آن است كه در زمان همه گيرى يكك بيمارى مانند كرونا، ترس از بيمارى و ترس از مرك،، در كنار آشفتكى

\footnotetext{
1 - Coronaviruses

2. COVID-19

3 - World Health Organization

${ }^{4}-\mathrm{Sa}$

5 - Wu \& McGoogan

${ }^{6}$ - Dong, Wang, Tao, Suo, Liu, Zhao \& Zhang

7- Valero- Moreno, Lacomba- Trejo \& Casana- Granell
} 
داشتهاند، هرجه سطح گشودخى بايينتر بـاشـد تحمل يريشانى نيز بايينتر است (جادورى، كوركيان و هاون،

.$(Y \cdot) 1$

در بررسى مطالعات ديخر، يزوهشخران گزارش كردند، مقابله هم بر تحمل يريشانى افراد در مواجهه با بران

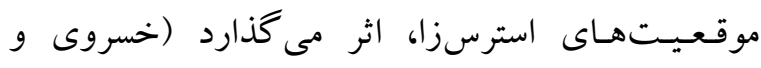

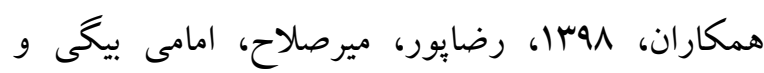

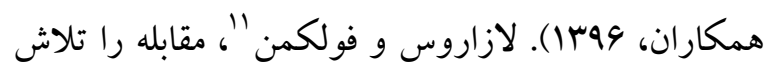

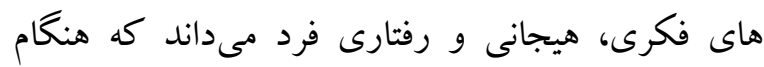
رويارويى با استرس به منظور غلبه كردن و تحمل كردن يا به حداقل رساندن عوارض استرس به كار مىبرد

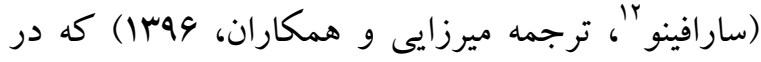

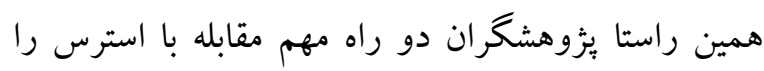
مطرح كردهاند: يكك روش شيوههاى ساز كارى متمركز بـر حل مسئله كه شامل فعاليتهاى مستقيم به منظور تغيير يا اصلاح شرايطى است كه تهديدآميز تلقى مى شود و دوم شيوههاى متمركز بر هيجان كه شامل فعاليتها و افكارى براى كنترل احساسات نامطلوبى دون

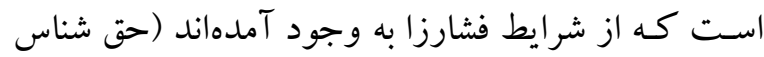

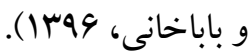

براساس مطالب بيان شده، تحمل بريشانى به طور فزاينده اى به عنوان يكك سازه مهم در ايجاد بينشهاى جديد در برد مورد شروع و ابقاء آسيب شناسى روانى همجنين

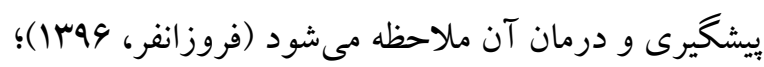
لذا به نظر مىرسد كشف عوامل مؤثر بر تحمل بريشانى

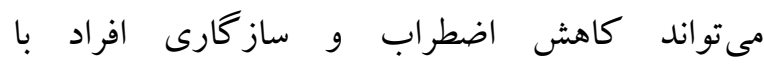
يريشانىهاى ناشى از دوران باندمى كرونا باشد. بر همين

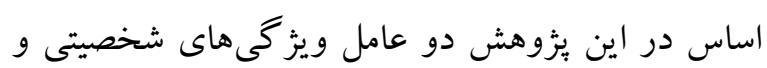

11- Lazarus \& Folkman

${ }^{12}$ - Sarafino
تحمل بريشانى، ممكن است بيشتر قادر باشند كه به

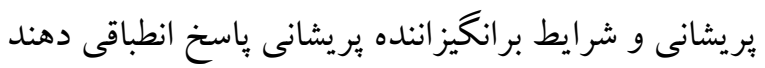

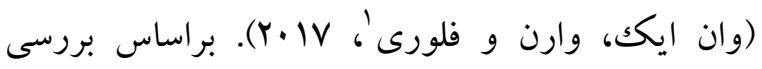
مطالعات بيشين ويزگىهاى شخصيتى بر مديريت

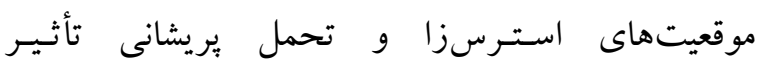
مى كذارند (جادورى، كوركيان و هاون'؛

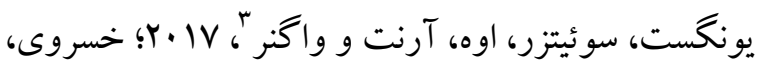
خسروى، كوشكى اوركى و طاووسى، 19 1). شخصيت مجموعه سازمان يافته و واحدى است متشكل از از

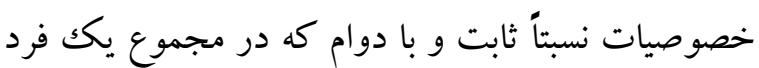

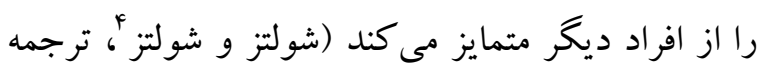

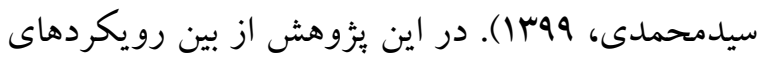
مختلف، نظريه بنج عاملى شخصيت مدنظر است كه شامل

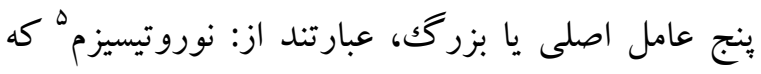

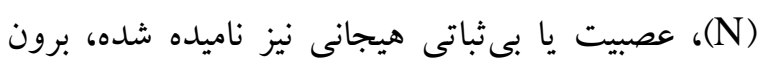

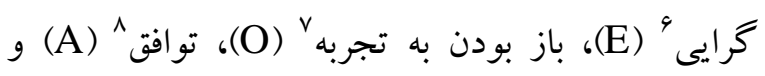

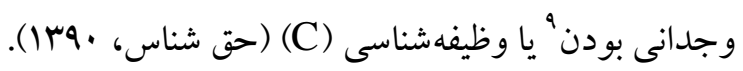

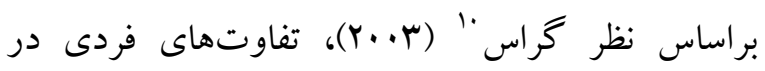
ويزگى هاى شخصيتى، منجر به تغيير در سطوح مختلف تحمل يريشانى مى شود و براى سببشناسى تحمل يريشانى بينشى مفيد فراهم مى كند (خسروى و همكاران،

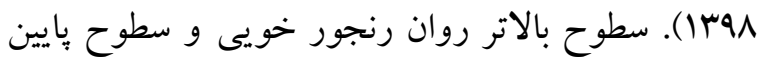
وجدانى بودن با تحمل يريشانى هايين رابطه دارند. برونخرايى بالاتر با تحمل بريشانى بالاتر در ارتباط است. در كسانى كه در مـعرض رويدادهـاى استرس زا قرار

\footnotetext{
1. Van Eck, Warren \& Flory

${ }^{2}$ - Kevorkian \& Hawn

3. Juengst, Switzer, Oh, Arenth \& Wagner

4- Schultz \& Schultz

5 - Neuroticisim

6- Extraversion

7. Openness

8 - Agreeableness

9 - Conscientiousness

${ }^{10}$ - Gross
} 
در نظر گرفته شدند. ملاككهاى خروج از يزوهش شامل عدم رضايت آزمودنىها براى شركت در يزوهش، تكميل ناقص :برسشنامها توسط آزمودنىها و قرار نداشتن آنها در بازه سنى مورد نظر بود. به منظور اجراى ليرسي يزٔوهش با توجه به محدوديت شيوع ويروس كرونا براى

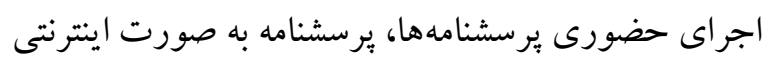

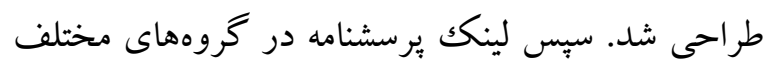

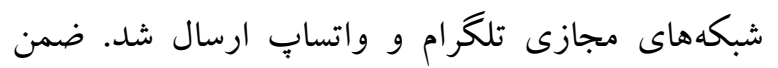
رعايت ملاحظات اخلاقى از جمله داشتن رضايت و آكاهى شركت كنند گان از شركت در ويزوهش، نبود

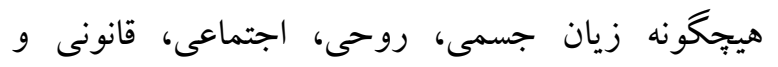
اقتصادى براى شركت كنند گان و حفظ اسرار آزمودنى ها در مرحله جمع آورى، انتقال و نگهدارى اطلاعات، از افر ادى كه حاضر به همكارى با بزوهشخر بودند و در رده سنى •و11 سال قرار داشتند، درخواست شد برسشنامه ها را به صورت دقيق و كامل تكميل نمايند. از بين

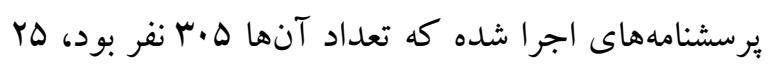
YA. برسشنامه مخدوش كنار كذاشته شد و در نهايت برسشنامه تكميل شده، به منظور تحليل وارد نرمافزار

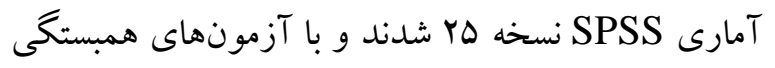
ييرسون و رگرسيون جند گانه تحليل شدند.

\section{ابز ار} يرسشنامه اطلاعات شخصى: در اين برسشنامه، ويز گیىهاى جمعيت شناختى شامل جنسيت، تأهل و تحصيلات مورد سنجش قرار گرفت. مقياس تحمل بريشانى '(DTS): اين مقياس توسط سيونز و

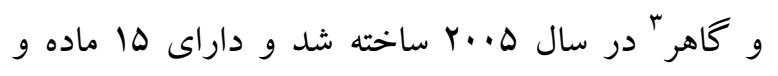

سبككهاى مقابلهاى به عنوان عو املى كه به نظر مىرسد در ميزان تحمل افراد در مقابل بريشانىهاى ناشى از بيمارى ويروس كرونا مؤثر هستند، مورد مطالعه قرار گرفته است. علاوه بر اين با توجه به شيوع سريع اين بيمارى و عدم تحقيق كافى در اين زمينه، به نظر مىرسد انجام تحقيقات براى كمكك به شناسايى بيامدهاى منفى اين بيمارى و به

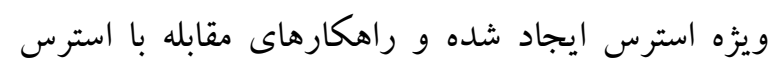
امرى ضرورى است و مى تواند به بهبود كيفيت زند مردم و سلامت جامعه كمك كند. يُزوهش حاضر از نوع مطالعات توصيفى - همبستخى بود.

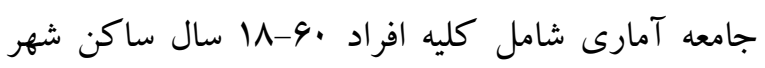
تهران بود كه در سال وهץ| به صورت اينترنتى در يزوهش شركت كردند. با توجه به اينكه اين يزوهش از نوع همبستكى بود، براى تعيين حجم نمونه از فرمول كرامر استفاده شد كه به ازاى هر سطح بيشبينى كننده F. نفر نمونه بايد در نظر كرفته شود (هويت و كرامر'،

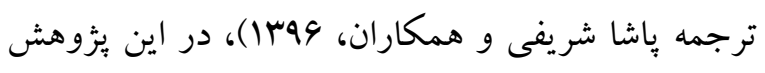
ويز كىهاى شخصيتى داراى ه سطح (بى ثابتى هيجانى، برون كرايى، باز بودن به تجربهها، توافق و وجدانى بودن) و راهبردهاى مقابلهاى داراى دو مؤلفه (مسئله مدار و هيجان مدار) بود كه جمعاً V سطح شد؛ در نتيجه نمونه

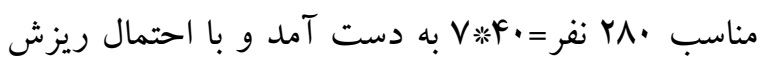

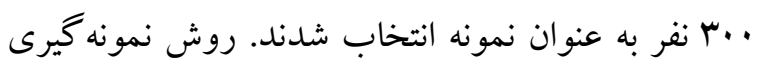
به صورت در دسترس انجام شد. سكونت در شهر تهران و داشتن حداقل تحصيلات سيكل و عدم ابتلا به بيمارىهاى خاص به عنوان ملاككهاى ورود در بئوهش حاضر

${ }^{2}$ - Distress Tolerance and Self-Regulation Questionnaire 
يرسشنامه شخصيت نئوب (NEO-FFI): اين برسشنامه در سال ه191 توسط مكك كرى و كاستا تهيه شده كه داراى 4 سؤال است و براى ارزيابى مختصر و سريع ه عامل اصلى شخصيت شامل روان آزرده گرايى، برون گرايى، باز بودن به تجربهها، توافق و وجدانى بودن طراحى شده و هر يكك از عوامل با سؤال مقياس را بوشش مىدهند نمره كذارى طيف ليكرت هـ درجهاى از · تا ع (كاملاً موافقم (Y)، اندكى موافقم (Y)، به يكك اندازه موافق و و مخالف (Y)، اندكى مخالفم (1) و كاملاً مخالفم (•) () (1) نمره گذارى شده است. در كل آزمودنى در هر مقياس نمرهاى از صفر تا FA كسب مى كند. لورى-يريتو،

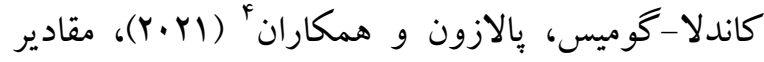

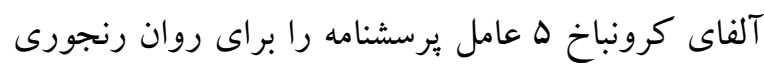

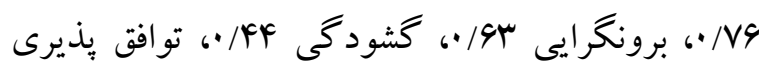

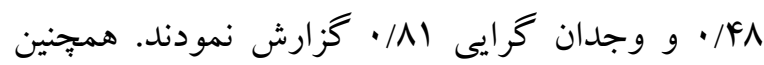
براساس يزوهش بنيسى (هوسا)، با توجه به ضرايب اعتبار

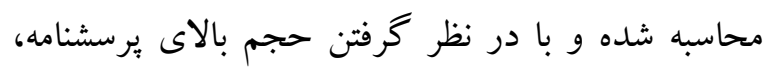
سؤالات مقياسها از همسانى درونى برخوردار بودند، به نحوى كه اعتبار مقياسهاى ينج گانه براساس محاسبه

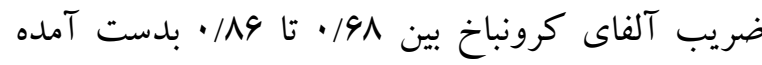

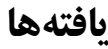

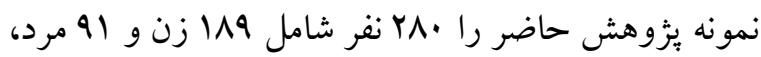
AF نفر مجرد و 199 نفر متأهل و داراى تحصيلات اY نفر لهر

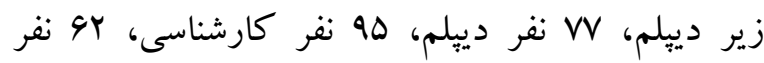
كارشناسى ارشد و YD نفر دكترى تشكيل دادند. در جدول ا، شاخصهاى توصيفى براى تمامى متغيرهاى

${ }^{3}$ - Neuroticism-Extraversion-Openness -Five-Factor Inventory

${ }^{4}$ - Luri-Prieto, Candela-Gomis \& Palazon et al
جهار خرده مقياس به نامهاى تحمل بريشانى هيجانى،

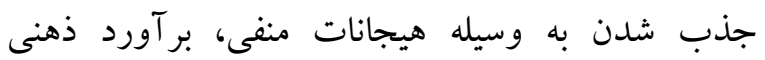
يريشانى و تنظيم تلاشها براى تسكين بريشانى است.

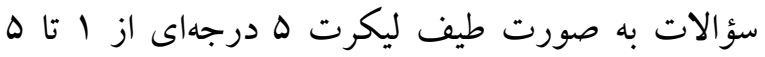

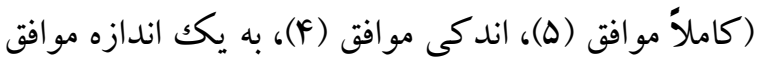
و مخالف (Y)، اندكى مخالف (Y) و كاملاً مخالف (1) (1) نمرهگذارى شده است. حداقل نمره آزمودنى در اين مقياس 10 و حداكثر VD است كه نمرات بالاتر نشاندهنده تحمل يريشانى بالاتر است. در يُوهش سيمونز،

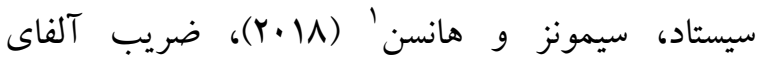
كرونباخ ra/· براى كل مقياس و براى خرده مقياسها

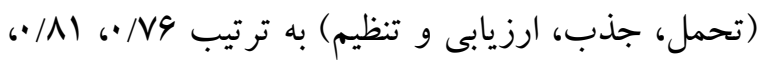

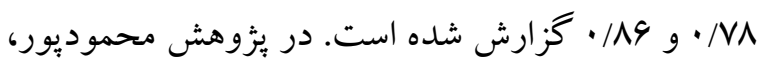
دهقانيور و وظيفه دان (99\%1)، ضريب آلفاى كرونباخ

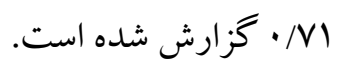
مقياس راهبردهاى مقابلهاى' (WOCQ): اين برسشنامه، توسط لازاروس و فولكمن (191ه) ساخته شده است و

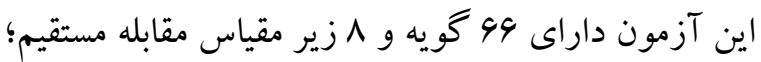

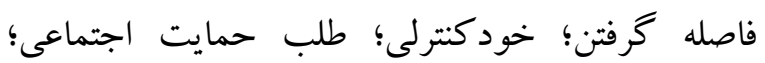
بذيرش مسئوليت؛ گريز-اجتناب؛ حل مسئله برنامهريزى شده؛ ارزيابى مجدد مثبت است. گُويههاى برسشنامه در

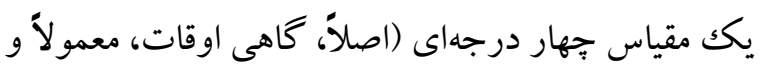
زياد) ارزيابى مىشود. اين برسشنامه در دو خوشه راهبردهاى مقابلهاى مسئله مدار و هيجان مدار طبقهبندى مى شود. بايايى اين آزمون در تحقيقى با استفاده از آلفاى

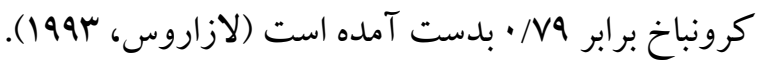

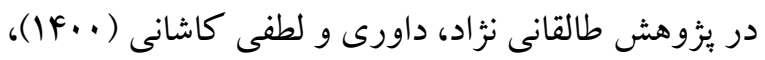
نيز بايايى اين آزمون برابر وه/• بدست آمده است.

\footnotetext{
1- Simons, Sistad, Simons \& Hansen

2. Ways Of Copying Questionnaire
} 
يثزوهش شامل ميانگين و انحراف معيار گزارش شده است.

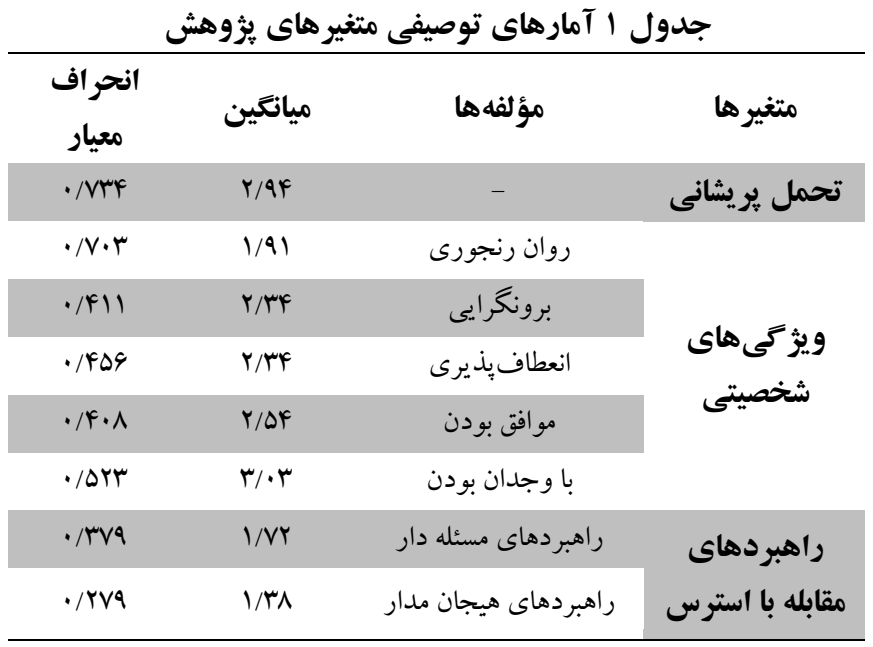

همبستكى ييرسون استفاده شد كه نتايج تحليل در جدول

براى بررسى همبستگى بين ويز كىهاى شخصيتى و

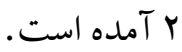
راهبردهاى مقابلهاى با تحمل بريشانى از آزمون ضريب لبري

جدول r نتايج آزمون همبستكى بيرسون بين ويزكى هاى شخصيتى و راهبردهاى مقابلهاى

\begin{tabular}{|c|c|}
\hline \multicolumn{2}{|c|}{ با تحمل يريشانى در دوران شيوع ويروس كرونا } \\
\hline ضريب همبستغى & متغير ها \\
\hline$*_{-} * /$ / & 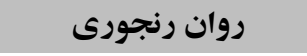 \\
\hline •/.r & برونكرايى \\
\hline$* . / \mathrm{TV}$ & انعطاف بذيرى \\
\hline$* . / / \uparrow \Lambda$ & 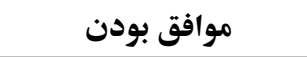 \\
\hline$* . / I r F$ & با وجدان بودن ل \\
\hline$* . /$ Irr & راهبردهاى مسئله دار \\
\hline$*_{-} \cdot / \mathrm{r}$. & راهبر دهاى هيجان مدار \\
\hline
\end{tabular}

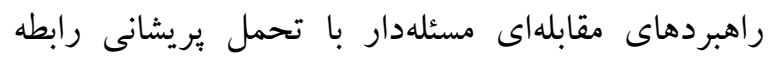
مثبت معنادار (ه/• (P<) و و بين راهبردهاى مقابلهاى هيجان مدار با تحمل بريشانى افراد در دوران شيوع كرونا رابطه منفى معنادار وجود دارد (ه•/•)

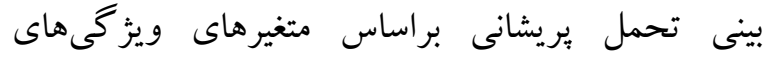

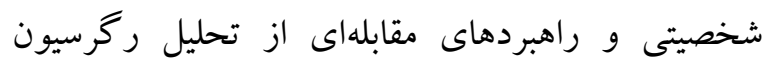

نتايج جدول Y نشان مىدهد، بين ويز گیىهاى شخصيتى انعطافيذيرى، موافق بودن و با وجدان بودن با تحمل

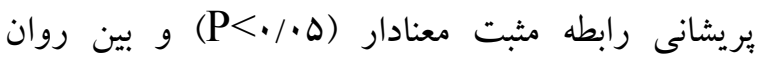
رنجورى با تحمل بريشانى افراد در دوران شيوع كرونا

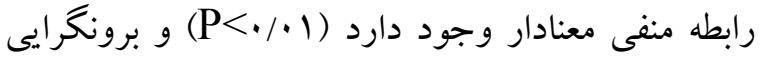
با تحمل پريشانى افراد رابطه ندارد. همجنين بين 


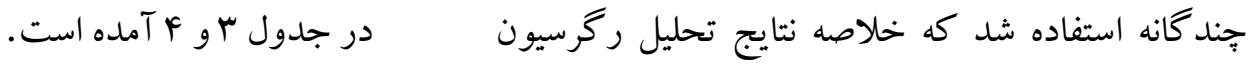

\begin{tabular}{|c|c|c|c|c|c|}
\hline \multirow{2}{*}{ معنىدارى سطح } & \multirow{2}{*}{$\mathbf{t}$} & \multirow{2}{*}{ ضر ايب استاندارد } & \multicolumn{2}{|c|}{ ضرايب غير استاندارد } & \multirow{2}{*}{ متغيرهاى ييشبين } \\
\hline & & & خطاى استاندارد & B & \\
\hline$\cdot / \cdots$ & $Q / Y Y I$ & - & $\cdot / F+1$ & r/qVG & ثابت \\
\hline$\cdot / \cdots$ & $-\Lambda / \Delta V Y$ & $-\cdot / \Delta r r$ & .1 .90 & $-\cdot / \Delta \Delta 9$ & روان رنجورى \\
\hline$\cdot / \cdots$ & $F / a r \Lambda$ & $\cdot / \mu 19$ &.$/ 11 F$ & $\cdot / \Delta \Delta \mid$ & برونكرايى \\
\hline$\cdot / \cdots$ & $r / 990$ &.$/ 19 V$ & $\cdot / \cdot \wedge 9$ & $\cdot / 419$ & انعطاف يذيرى \\
\hline$\cdot 1 \cdot 49$ & $r / 1.9$ & $\cdot / 1 r$. & $\cdot / 1 \cdot r$ & $\cdot / Y 19$ & موافق بودن \\
\hline - /AFF &.$/ 19 V$ &.$/ \cdot 1 r$ & $\cdot / \cdot \wedge F$ &.$/ \cdot 1 V$ & با وجدان بودن \\
\hline
\end{tabular}

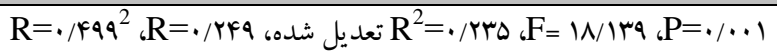

بودن رابطه معنادارى در معادله يافتند كه نشان مىدهد كه اين F متغير تو انستهاند در مجموع ه/ Ir/ درصد از واريانس تغييرات مربوط به متغير تحمل بريشانى افراد را در دوران شيوع كرونا تبيين نمايند ( ( + (P=•).
براساس جدول سا، نتايج بيانكر آن است كه از متغيرهاى وارد شده به معادله رگرسيون (ويز گىهاى شخصيتى روان

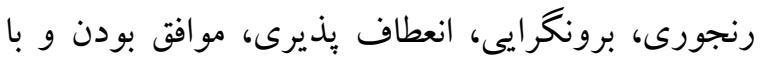
وجدان بودن) به جز متغير ويز گیى شخصيتى با وجدان

\begin{tabular}{|c|c|c|c|c|c|}
\hline \multirow{2}{*}{ معنىدارى سطح } & \multirow{2}{*}{$\mathbf{t}$} & \multirow{2}{*}{ ضرايب استاندارد } & \multicolumn{2}{|c|}{ ضرايب غير استاندارد } & \multirow{2}{*}{ متغير هاى بيشبين } \\
\hline & & & خطاى استاندارد & B & \\
\hline$\cdot / \cdots$ & $1 Y / \mu 19$ & - & . / YFY & Y/QVD & ثابت \\
\hline$\cdot / \cdots$ & r/qTr & . &.$/ I Y V$ & $\cdot / F \& Y$ & راهبردهاى مسئله دار \\
\hline$\cdot / \cdot \cdot 1$ & $-r / \Delta \cdot V$ & - & $\cdot / \mathrm{IVT}$ & $-\cdot 19 \cdot V$ & راهبردهاى هيجان مدار \\
\hline
\end{tabular}

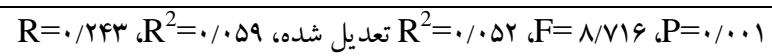

يزوهش حاضر با هدف تعيين نقش ويز گیىهاى شخصيتى

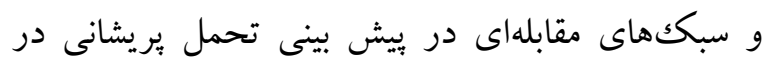
دوران شيوع ويروس كرونا انجام شد. يافته حاصل نشان

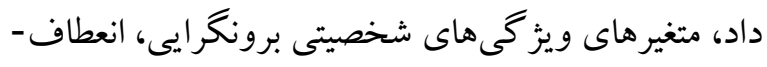
يذيرى و موافق بودن تأثير مثبت و روان رنجورى تأثير منفى بر ميزان تحمل بريشانى افراد در دوران شيوع كرونا دارند. روان رنجورى بيشترين تأثير و موافق بودن كمترين

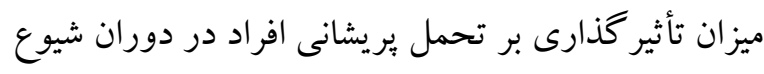

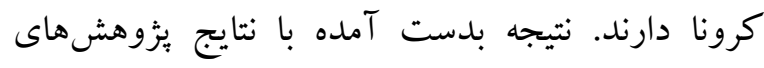

براساس جدول F، نتايج بيانگر آن است كه متغيرهاى وارد

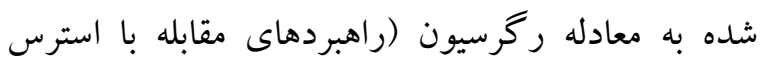
مسئله دار و هيجان مدار ) رابطه معنادارى در معادله يافتند كه نشان مىدهد كه اين راهبردهاى مسئلهار و هيجان مدار توانستهاند در مجموع ه درصد از واريانس تغييرات مربوط به متغير تحمل بريشانى افراد را در دوران شيوع كرونا

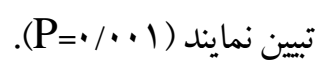


هيجانات مـنفى تلاش كرده و بـراى بيكيرى فرصت-

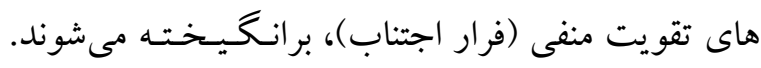
حساسيت بالاى سيســتم بــازدارى رفتارى كه در روانرنجور خويى و ... نمود مىيابد، باعث مىشود افراد

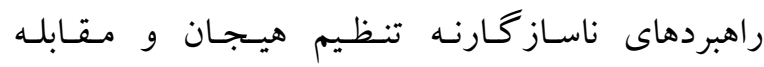

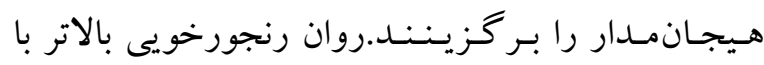
كاربرد بيشتر سركوب همراه است و ميان وجدانى بودن بـا ارزيابى مـجـدد شناختى رابطه مثبت وجود دارد.

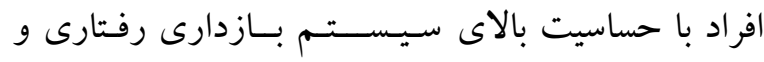
حساسيت بايين سيستم فعالسـاز رفتارى مشكلات تنظيم هيجان بيشترى دارند (خسروى و همكاران، يوسا). به نظر مىرسـد افرادى بـا روان رنجور خويى بالا، در شرايط

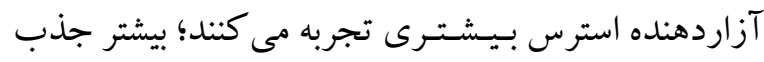
هيجانات منفى مىشوند و ارزيابى نادرستى از بريشانى

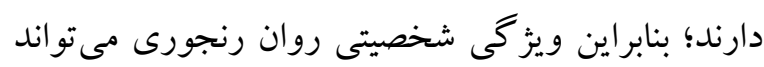
از طريق تنظيم هيجانات منفى، تحمل بايين ترى هنكام مراجعه با شرايط تنشزايى از جمله شيوع يكك بيمارى تئي واكيردار از خود نشان دهند. ويزگى شخصيتى ديخرى كه با تحمل بريشانى رابطه

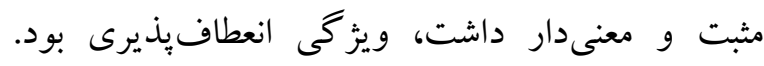

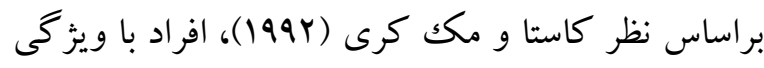
شخصيتى انعطاف يذيرى، مايل به بذيرش عقايد جديد و ارزشهاى غيرمتعارف بوده و عميقتر از اشخاص غير منعطف هيجانهاى مثبت و منفى را تجربه مى كندا؛ بنابراين در شرايط غيرمتعارف شيوع ويروس كرونا دران جامعه، اين افراد توانيى بيشترى براى تحمل ابهام و و شرايط جديد از خود نشان مىدهند و توانيى كنترل

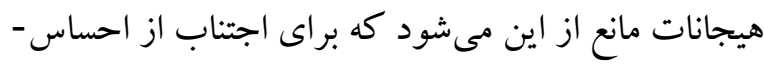

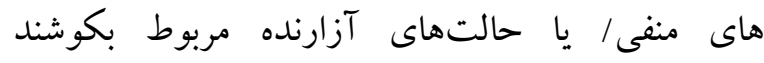

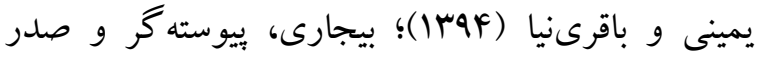
( همكاران (1) (Y) همسوئى دارد. براساس نتايج اين

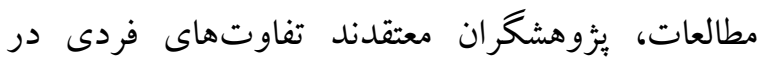
ويزگى هاى شخصيتى، منجر به تغيير در سطوح مختلف

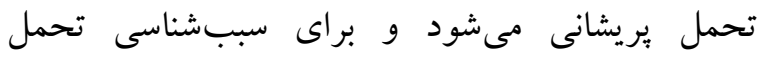
بريشانى بينشى مفيد فراهم مى كند. علاوه بر اين مطالعات، در اين راستا نتايج يزوهش تابع بردبار، عيسى خانى و و

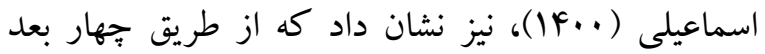
شخصيتى (توافق يذيرى، برون گرايى، انعطافيذيرى و وجدانى بودن) به صورت معكوس و بعد روانرنجورخويى به صورت مستقيم، ميزان اضطراب ناشى از

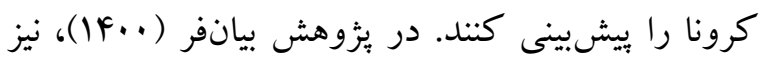
دو ويزگى شخصيتى انعطاف يذيرى و وجدانى بودن در ييشينى اضطراب كرونا نقش معنادارى نشان دادند. در تبيين نتيجه بدست آمده مىتوان عنوان نمود، با توجه به لفه اينكه روانرنجورخويى در بركيرنده تمايل به داشتن هيجانات منفى، مقابله ضعيف و كنترل دشوار

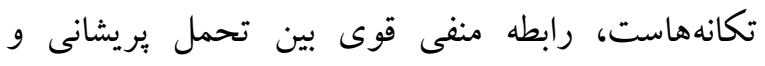

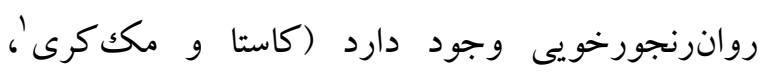

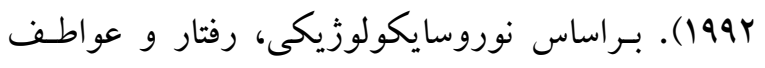
بهـ وسيله تفاوتهاى فردى در سيستمهاى زيستى

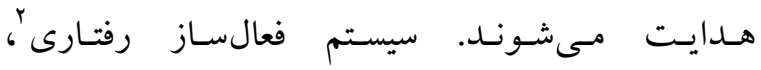

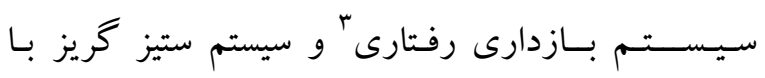
عواطف منفى، صفات شخصيتى اضطرابى و رفتارهاى مرتبط بـا اضطراب مثل نشخوار فكرى رابطه دارد كه اثر مستقيم ويزگى هاى شخصيتى بر تحمل بريشانى را تبيين

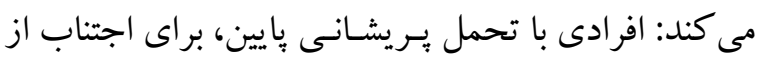

\section{Costa \& McCrae}

2 - Behavioral Activation System (BAS)

3 - Behavioral Inhibition System (BIS) 
مىنمايد كه همين توانيى ارائه راه حل به جاى اجتناب از رويارويى با مسائل مىتواند در شرايط استرسزاى بيمارى كرونا، به فرد كمكك كند تا رفتار و عملكرد معقول ترى از خود نشان داده و به جاى رفتارهاى هيجانى نامطلوب، به مديريت وضعيت روانى و جسمانى خود و اطرافيانش بيردازد. اين در حالى است كه در مقابله هيجانمدار، فرد به جاى تمركز بر خود مسئله بر هيجانات ناشى از آن تمركز كرده و به جاى حل مشكل براى كاهش دادن هيجانات منفى تلاش مى كند؛ به عبارت ديخر به صورت ناكار آمد با مشكلات برخورد مىنمايد و كه اين مسئله منجر به مشكلات بيشتر براى آنها مىشود و در جرخهاى معيوب با فعال شدن هيجانات منفى، به ميزان يريشانى فرد

$$
\text { و اطر افيانش افزوده شود. }
$$

\section{نتيجه كيرى}

براساس يافتهاى حاصل از يزوهش حاضر مى توان نتيجه

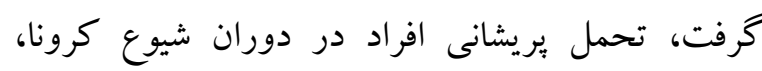
براساس ويز گیىهاى شخصيتى آنها به ويزه ميزان روان رنجورى و همجنين سبك هاى مقابلهاى آنها در برابر يريشانىها و تنشهاى ناشى از اين بيمارى كه در سطح جامعه گسترده شده است، ارتباط دارد. در راستاى محدوديتهاى يثزوهش حاضر مىتوان به شيوه مطالعه حاضر كه از نوع همبستخى بود اشاره كرد؛ لذا نمىتوان روابط را على تفسير كرد كه بيشنهاد مىشود در

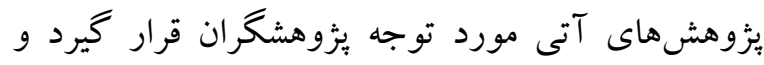
مطالعات آزمايشى و فرا تحليل در اولويت باشد. همجينين ييشنهاد مى شود در يُزوهش هاى بعدى، به منظور اطمينان

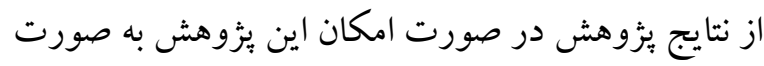
حضورى در بين افراد نمونه اجرا گردد. همجينين

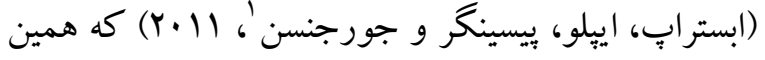
موارد از ويز گیى هاى افراد با تحمل بريشانى بالاست. يكى ليكى ديخر از ويزگى شخصيتى مرتبط با تحمل بريشانى وجدانى بودن، بود، در اين افراد، ميزان انخيزش، سازماندهى و بِيدارى در رفتارهاى هدفمند بالاتر است

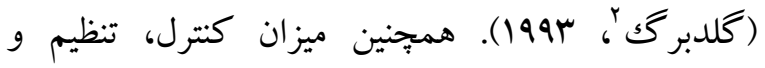
هدايت تكانها در اين افراد مشاهده مىشود كه در شرايط استرسزاى بيمارى كرونا كمكك مى كند تا اين افراد ميزان رفتارهاى تكانهاى كمترى داشته و با بان هوشمندى بيشترى، حالتهاى هيجانى منفى را تجربه و

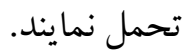
براساس بخش ديخرى از يافتها، متغير راهبردهاى مسئلهار تأثير مثبت و راهبردهاى هيجانمدار تأثير منفى برى بر ميزان تحمل بيريشانى افراد در دوران شيوع كرونا دارند. كه نتيجه بدست آمده با نتايج بزوهش سليمانى و

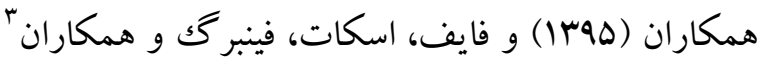
همسوئى دارد. در اين راستا فايف و همكاران (Y..人) دريافتن افراد تابآور تمايل بيشترى براى (Y.人) استفاده از راهبرهاى مقابلهاى مسئله محور دارند و استفاده از اين سبككهاى مقابلهاى، احتمال اكتساب بيمارىها را كاهش و تمايل افراد را براى دريافت خدمات سلامت افز ايش مى دهد. در تبيين نتيجه بدست آمده مى توان استدلال نمود، افرادى

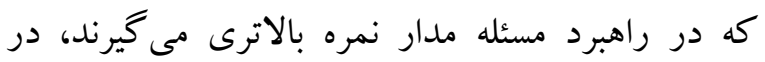
مواجهه با مشكلات زندكى مسئله اصلى را تعيين مى كنند

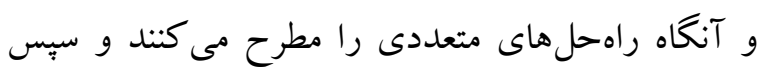
مزاياى هر كدام از اين راهحلها را مىسنجند و در نهايت يكى از اين راهحل ها را انتخاب نموده و براساس آن عمل

\footnotetext{
1- Ebstrup, Ebstrup, Eplov, Pisinger \& Jorgensen

2 - Goldberg
}

${ }^{3}$ - Fife, Scott, Fineberg, Zwickl \& et al 
adults. Personality and individual differences. 120, 166-170.

Costa JR, PT, McCrae RR. (1992). Four ways five factors are basic. Personality and individual differences. 13(6), 653-665.

Dong X, Wang L, Tao Y, Suo X, Li Y, Liu F, Zhao Y, Zhang Q. (2017). Psychometric properties of the Anxiety Inventory for Respiratory Disease in patients with COPD in China. Int J Chron Obstruct Pulmon Dis. 12,49-58.

Fife BL, Scott LL, Fineberg NS, Zwickl BF. (2008). Promoting adaptive coping by persons with HIV disease: evaluation of patient/partner intervention, odel. The Joumal of the Association of Nurses in AIDS Care. 19(1), 75-84.

Fischhoff B. (2020). Speaking of Psychology: Coronavirus Anxiety. In: https://www.apa.org/research/action/speakingof-psychology/coronavinus-anxiety.

Forouzanfar A. (2017). Distress tolerance: Theory, Mechanism and Relation to Psychopathology. Rooyesh. 6(2), 239-262. (In Persian)

Goldberg LR. (1993). The structure of phenotypic personality traits. American psychologist, 48(1), 26.

Haghshenas H. (2011). The five-factor scheme of personality traits: A guide to the interpretation and norms of the NEOPI-R and NEOFFI tests. Shiraz, Shiraz University of Medical Sciences Publications. (In Persian)

Haghshenas S, Babakhani N. (2017). Predicting marital satisfaction based on stress coping skills and time perspective. Family Research Quarterly. 52, 584-569. (In Persian)

Howitt D, Cramer D. (2017). Statistical methods in psychology and other behavioral sciences. (translation: Pasha Sharifi H, Najafizadeh J, Mir Hashemi M, Manavipour D, Sharifi N). Tehran: Sokhan.

Juengst SB, Switzer G, Oh, BM, Arenth PM, Wagner AK. (2017). Conceptual model and cluster analysis of behavioral symptoms in two cohorts of adults with traumatic brain injuries. Joumal of clinical and experimental neuropsychology, 39(6), 513-524.

$$
\begin{aligned}
& \text { متغيرهاى سلامت روان، وضعيت اقتصادى و اجتماعى } \\
& \text { كنترل شود و به دليل محدوديتهاى برسشنامه بهتر است } \\
& \text { از روشهاى ديخر مانند مصاحبة ساختار دار و بى ساختار }
\end{aligned}
$$

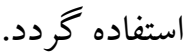

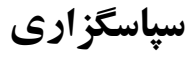

$$
\begin{aligned}
& \text { از تمامى افرادى كه در اين مطالعه شركت كردند و در } \\
& \text { انجام اين يزوهش ما را يارى نمودند كمال تشكر را }
\end{aligned}
$$

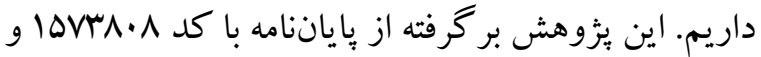

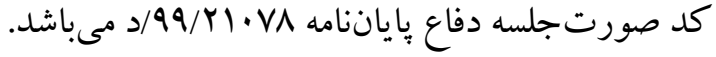

\section{References}

Alipour A, Ghadami A, Alipour Z, Abdullahzadeh H. (2019). Preliminary validation of the Corona Anxiety Scale (CDAS in the Iranian sample. Scientific Joumal of Health Psychology. 8, 4(32), 175-163. (In Persian)

Banisi P. (2016). Validity and Reliability of Neo Personality Questionnaire among Students of Selected Universities in Tehran. The First National Congress of Community Empowerment in the Field of Sociology, Educational Sciences and Social and Cultural Studies, Tehran. (In Persian)

Bayanfar F. (2021). Predicting corona disease anxiety among medical staffs in Tehran based on Five Factor theory of personality. Iranian Joumal of Health Psychology. 2(2), 113-126. (In Persian)

Bijari F, Peyvastehgar M, Sadr MS. (2015). The Relationship between Resilience and the Five Dimensions of Personality and Clinical Disorders of Depression, Anxiety and Physicalization in Undergraduate Students of Al-Zahra University. Psychological Studies. 11 (3), 53-78. (In Persian)

Chowdhury N, Kevorkian S, Hawn SE, Amstadter AB, Dick D, Kendler KS, Berenz EC. (2018). Associations between personality and distress tolerance among trauma-exposed young 
Khosravi N, Shirin Kooshki M, Oraki MR, Tavousi N. (2019). Structural pattem of personality traits and emotional cognitive regulation with distress tolerance in mothers with children with cancer: The mediating role of coping strategies. Quarterly Journal of Nurse and Physician in Warfare. 24, 7, 72-82. (In Persian)

Kratovic L, Smith LJ, Vujanovic AA. (2021). PTSD symptoms, suicidal ideation, and suicide risk in university students: The role of distress tolerance. Joumal of Aggression, Maltreatment \& Trauma. 30(1), 82-100.

Lazarus RS, Folkman S. (1984). Coping and adaptation. In: Gentry WD, Editor. Handbook of behavioral medicine. New York, NY: Guilford Press.

Luri-Prieto P, Candela-Gomis A, Palazon-Bru A, Navarro-Cremades F, Gil-Guillen VF, Compan-Rosique AF. (2021). Impact of Anal Fissure on Neuroticism, Extraversion, Openness to Experience, Agreeableness, and Conscientiousness: A Case-Control Study. Visceral Medicine. 37(1), 1-6.

MacKillop J, De Wit H. (Eds). (2013). The WileyBlackwell Handbook of Addiction Psychopharmacology. John Wiley \& Sons.

Mahmoudpour AB, Dehghanpour S, Vazifehdan F. (2020). Predicting distress tolerance based on attachment styles, tolerance of failure and religious attitude in divorced women. The Rise of Psychology. 4(49), 103-93. (In Persian)

Reza Pour Mir Saleh Y, Ismail Beigi M. (2017). The relationship between flexibility and distress tolerance mediated by a negative orientation to the problem of homeless and abused adolescents. Social Work Quarterly. 6 (3), 22 31. (In Persian)

SA RRK. (2020). "Brief review of coronavirus for healthcare professionals February 10, 2020. Southw est Joumal of Pulmonary and Critical Care. 20(2), 69-70.

Sarafino AP. (2020). health Psychology. Translated by Elahe Mirzaei et al. Roshd Publications, 8th edition.

Schultz DP, Schultz SE. (2020). Theories of personality. Cengage Learning. (Translated by Seyd
Mohammadi, Y). Tehran: Editing. 10th edition.

Simons J, Gaher R. (2005). The Distress Tolerance Scale: Development and validation of a selfreport measure. Motivation and Emotion. 29, 83-102.

Simons RM, Sistad RE, Simons JS, Hansen J. (2018). The role of distress tolerance in the relationship between cognitive schemas and alcohol problems among college students. Addictive behaviors. 78, 1-8.

Soleimani I, Babaei K, Atadokht A. (2016). Investigating the distinguishing role of psychological resilience and emotion-oriented and problem-oriented coping styles in predicting students' psychological disturbance profile and comparing it by gender. Culture in Islamic University. 6 (19), 233-250. (In Persian)

Tabe Bordbar F, Eisakhani S, Esmaeili M. (2021). The role of personality characteristics and source of health control in predicting corona anxiety in women. Joumal of Clinical Psychology. 13(3), 20-33. (In Persian)

Taleghaninejad MA, Davari R, Lotfi Kashani F. (2021). Prediction of Internet addiction based on perceived social support, stress coping styles and emotional intelligence in students. Journal of Information and Communication Technology in Educational Sciences. 11 (3 (43)), 109-129. (In Persian)

Valero-Moreno S, Lacomba-Trejo L, Casana-Granell S. (2020). Psychometric properties of the questionnaire on threat perception of chronic illnesses in pediatric patients. Revista Latinoamericana de Enfermagem. 28:e3242.

Van Eck K, Warren P, Flory K. (2017). A variablecentered and person-centered evaluation of emotion regulation and distress tolerance: links to emotional and behavioral concerns. Journal of youth and adolescence. 46(1), 136-150.

World Health Organization. (2020). Coronavinus disease 2019 (COVID-19) situation report-34. World Health Organization. https://apps.who.int/iris/handle/1 $0665 / 331220$. 
q9 رابطه ويزگى هاى شخصيتى و سبكهاى مقابلهاى با تحمل يريشانى در دوران شيوع ويروس كرونا

Wu Z, McGoogan JM. (2020). Characteristics of and Important Lessons From the Coronavinus Disease 2019 (COVID-19) Outbreak in China: Summary of a Report of 72314 Cases From the Chinese Center for Disease Control and Prevention external icon. JAMA. Published online: February 24.

Yamini M, Bagherinia H. (2015). The Relationship between Coping Styles and Five Factors of Patience Pattem, 2nd Intemational Conference on Psychology, Educational Sciences and Lifestyle, Mashhad. (In Persian) 